\title{
Product Mix and Pricing Strategies of Retail Establishments: An Exploratory Study in Mizoram
}

\author{
${ }^{1}$ Lalchhantluangi Pachuau, ${ }^{2}$ Prof. NVR Jyoti Kumar \\ ${ }^{1}$ Ph.D Research Scholar, Department of Commerce, Mizoram University, Aizawl, 796004 \\ ${ }^{2}$ Proffesor \& Supervisor, Department of Commerce, Mizoram University, Aizawl, 796004
}

\begin{abstract}
This research paper provides an overview of the retailers of 5 categories namely- apparel, household appliances, food and grocery, mobile phones and cosmetics in Mizoram with special reference to Aizawl taking into account their product mix and pricing mix in a city where almost all businesses are retails where production of own products is still sparce and countable in the state. The study uses SPSS for data analysis with measures of central tendency i.e mean value along with weighted score and percentage to Maximum Possible Score (MPS) to find out the various product mix selection as well as the pricing of products. This study will help existing and upcoming retailers on how they would strategize their target market to its maximum possibility. The study gives an overview and understanding on how retail markets work in the city of Aizawl and how markets have thrived under their strategies adopted.
\end{abstract}

Keywords: retailers, marketing, product mix, pricing, analysis

\section{INTRODUCTION}

Marketing is about the identification and meeting of the needs and wants of social beings. It is a societal process by which individuals and groups obtain what is needed and what is wanted by creating, offering and freely exchanging goods and services of value amine one another (Kotler, et al, 2009). It can also be defined as the art and science of choosing target markets thereby getting, securing and expanding the customer base through creation, delivery and communication of superior customer value (Rein and Haider, 2008).

A marketer can never satisfy everyone in the market due to indifferences of needs, wants and desires. As such, marketers divide the market into segments for the identification of distinct groups of people with similar wants and needs (Shapiro, 2008) The main aim of every marketer is to satisfy the target markets through positioning of such marketed products to deliver central benefits (Kotler, 2010). Business requires value propositions and lay down benefits to satisfy the customers through product offerings with a combination of services, products, information and experiences (Kamenetz, 2006). Offerings become successful only of only if it is accompanied by value and satisfaction among the consumers. Value reflects the combination of quality, service and price providing the sum of tangible and intangible benefits to match the cost (Kotler, et al 2009).

Retailing can be defined as a distribution channel function, where an organization buys products from supplying firms or manufacturers and sell these products directly to customers. Retailing plays a significant role for both customers and sellers since it enables the customers to purchase small quantities of an assortment of products at reasonable and affordable price and offers an opportunity to suppliers in identifying their target market. Through retail promotions, such sellers can build a strong product demand and provide customer feedback to the marketer as well as the manufacturer (Dun and Bradstreet,2009). Retail is the display of products, the description of its features and its corresponding benefits, stocking of products, processing of payments and getting the right products at the right price to the right customers at the right time (Farfan, 2019).

Product is the tangible good offered to the consumer and any marketer has to address 5 core market plan namely:

The core benefit- the benefit or service the customer is actually buying

The second level- transformation of the core benefit to basic product

The third level- preparation of expected product which comprises of sets of attributes and conditions that the customers would normally expect upon purchase of the product

The forth level- preparation of augmented product that would surpass the customers' expectations

The fifth level- preparation for the potential product that would envision all possible augmentations and transformations the product or service might undergo in the foreseeable future (Koshy and Keller , 2016)

For any competition to survive, product differentiation is required. Products can have many forms such products must be differentiated in form, size, shape, structure and utilization. Products offer variant features and as such marketers should be well versed in differentiating their products and introduce them to the market as and when required (Boyd and Levy,2001). Product line offerings is a staple for any business to thrive by provision of various shapes and sizes of the 


\title{
International Advanced Research Journal in Science, Engineering and Technology
}

\author{
Vol. 8, Issue 8, August 2021
}

\section{DOI: 10.17148/IARJSET.2021.8863}

products offers to satisfy customer requirements and as such marketers require to have knowledge on the sales and profits of each item on the line to determine the items to be build, maintain, harvest or divest (Roa,2013).

Pricing is not just a number placed on a tag but is the sum total of several components to determine the monetary value of a product or service (Vasu, 2019). Many economists assume that the consumers' are price takers that accept prices as given. However recent arguments have shown that consumers have played an active role in the pricing of products and are not only the takers of the value assigned to the products (Roberts, et al 2009). Purchase decisions are now commonly based on how a buyer perceive the prices and what they consider the current price to be and not the marketers' stated price (Vijayan, 2020)

\section{LITERATURE REVIEW}

Egan (2000) studied the driving forces of relational strategies in retailing and explored the universal application of Relationship Marketing Strategies and its relevance across retailing. He found that FMCG market recognition is the prime driver to adopt relational approach. The study also shows that there is direct relationship between emotional attachment and value of benefit. The relationship comes to top priority when a consumer identifies the need for trust and the value of commitment.

Bronnenberg \& Albuquerque (2002) studied the geography and marketing strategy of packaged goods in retail stores. The study found that the geographical space and location are important ingredients of marketing strategy and practice. The study further found that the following are ingredients that makes physical space relevant: special price discrimination, sustenance of market power, consumer immobility, cost of transportation, advertising 'markets' retailer trade areas and distributional channels.

Adewale \& Oyewale in their study on the impact of marketing strategy on the performance of retail SME's in Nigeria found that the following strategies of the 4 P's - Product, Place, Price and Packaging are notably independent but are the joint predicators of performance. The study also revealed that promotional strategies have no significant impact on the performance of business.

Cant, et al (2015) in their study on the product strategies of SME's of Retailing took into account the decisions of marketing of products and found that the main aim of the SME's is to satisfy the needs and wants of their customers through the offerings of their products. The study concluded that the main aim of SME's should be to select and sell the right products for the right customers through surveys and word of mouth.

Shankalia, et al (2018) in their study of the retailing business of Apple Products found that marketing strategies should result in the positive review in terms of its marketing activities since most apple products are high end and expensive and its advantage and uniqueness must be highlighted especially if they are sold by retailers. Target market and value proposition must also be defined in a specific manner so as to increase sales.

Bijmolt et al (2019) studied the challenges of marketing in omni-channel retail environments and found that the most significant interdependency exist across the customer journey (demand-side) and the product flow (supply side) thereby creating significant challenges and opportunities for firms. The study reveals three interdependent key design decisions i.e. assortment \& inventory, distribution \& delivery and returns.

\section{OBJECTIVES OF THE STUDY}

a. To Identify the best strategies of the product mix of retailers

b. To Identify the best strategies of the pricing mix of retailers

\section{RESEARCH METHODOLOGY}

Method of Study: The study is an Exploratory Research to understand in detail the concept and extent of retail marketing in Aizawl City

Data Collection:

Primary Data: The study depends mostly on primary data sources. Primary data is collected through structured questionnaire for retailers in Aizawl City who are registered under the Department of Taxation, Government of Mizoram. The information related to policies, practices and opinion of retailers is collected and analyzed.

Secondary Data: Secondary data is collected from Government reports i.e Statistical Handbooks, Taxation Department, Govt. of Mizoram, reports of previous researches, academic journals, trade associations, magazines, newspapers and records of small scale retail units proposed to be studied.

Scope of Coverage: The study covers small scale retail units in Aizawl City who are Tax Assesses under the Department of Taxation, Government of Mizoram. For the purpose of the study, five retail categories are selected based on the number of retailing units in Aizawl City. The five categories of retail selected for the study are:

i) Apparel

ii) Electricals and Electronics

iii) Food and Grocery 


\section{International Advanced Research Journal in Science, Engineering and Technology}

Vol. 8, Issue 8, August 2021

DOI: 10.17148/IARJSET.2021.8863

iv) Mobile Phones

v) Cosmetics

Area of Coverage: The area of study is limited to Aizawl City since majority of the retail units are located within the city( Personal interview with Mr.Kailiana Ralte, Commissioner of State Tax, Government of Mizoram). The study is divided in zonal areas since secondary data of Retailers is obtained based on zonal areas of Aizawl District i.e. North Zone, South Zone, West Zone and East Zone.

Sample Size: 30 retail units under each of the five categories under study.

\section{5.}

\section{ANALYSIS AND INTERPRETATION}

\section{Analysis of Demography of Retailers}

Figure 1. Age of Retailers
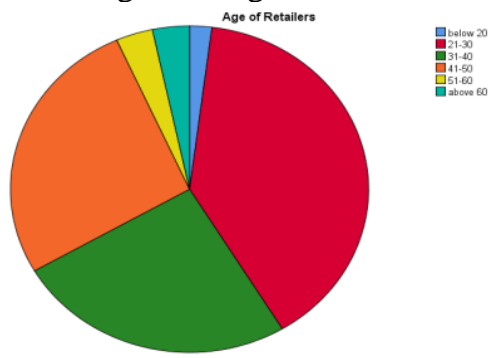

Source: Primary Data

Figure 1 represents the combined data of ages of all the 150 retailers under study. It can be seen that majority of the retailers belong to the age group of 21-30 years old follows by the age group 31-40 and 41-50 years of age. Thus, we can infer that most of the retailers are belong to the younger age group than that of older age group.

Figure 2: Gender of Retailers

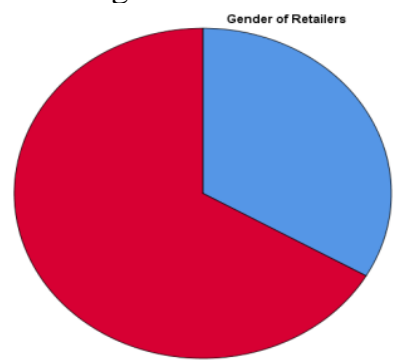

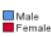

Source: Primary Data

Figure 2 represents the overall gender distribution among all retailers understudy. As shown in the figure it can be said that majority of the retailers are women. It can be concluded that within the study, more women are leaning towards the retail industry in Mizoram as compared to the Mizo men .

Figure 3: Education of Retailers

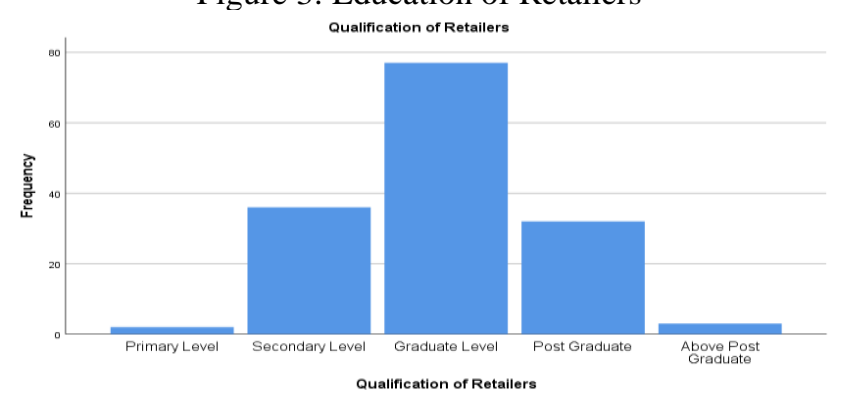

Source: Primary Data

Figure 3 shows the different educational qualifications of the 150 retailers understudy. As can be seen from the figure, majority of the respondents have Graduate Level education followed by the secondary level. The third highest qualification is the Post Graduate degree and educational level of primary and above post graduate contribute the least among all the retailers. 


\section{DOI: $10.17148 /$ IARJSET.2021.8863}

From the above analysis, it can be inferred that most mizo's with graduate degree start up their businesses as retailers and it can also be inferred that those with above post graduates do not necessarily lean to setting up businesses since most Mizo's who go for above post graduate studies lean more towards academic line rather than setting up businesses.

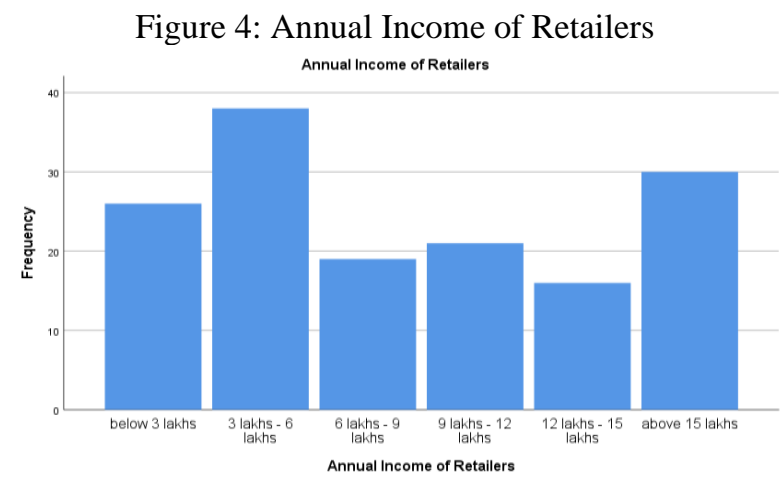

Source: Primary Data

Figure 4 shows the combined data of annual income of all the retailers under study. The above figure shows that majority of the retailers earn income between 3-6 lakhs followed by the income group of above 15 lakhs. The third most earned income belongs to the income group of below 3 lakhs. From the above analysis, it can be seen that there are huge jumps and variations when it comes to the income earned by the retailers since the majority and the second highest have a massive difference of around 11 lakhs.

\section{Analysis of Product Mix of Retailers}

Table 1: Influencing Factors in deciding Product Mix

(Score)

\begin{tabular}{|c|c|c|c|c|c|c|}
\hline Particulars & Apparel & $\begin{array}{l}\text { Household } \\
\text { Appliances }\end{array}$ & $\begin{array}{l}\text { Food \& } \\
\text { Grocery }\end{array}$ & $\begin{array}{l}\text { Mobile } \\
\text { Phones }\end{array}$ & Cosmetics & Total \\
\hline Financial Strength & 15 & 7 & 19 & 5 & 12 & 58 \\
\hline Weighted Mean & 1.88 & 1.40 & 2.11 & 1.25 & 1.50 & 1.63 \\
\hline$\%$ to MPS & 62.66 & 46.66 & 70.33 & 41.66 & 50 & 54.26 \\
\hline Profit Margin & 38 & 46 & 45 & 12 & 40 & 181 \\
\hline Weighted Mean & 1.73 & 1.92 & 2.50 & 1.50 & 2.50 & 2.03 \\
\hline$\%$ to MPS & 57.66 & 64 & 83.33 & 50 & 83.33 & 67.66 \\
\hline Demand from Customers & 58 & 75 & 50 & 77 & 65 & 325 \\
\hline Weighted Mean & 2.00 & 2.59 & 2.38 & 2.85 & 2.41 & 2.45 \\
\hline$\%$ to MPS & 66.66 & 83 & 79.33 & 95 & 80.33 & 80.86 \\
\hline Pressure from Customers & 3 & 0 & 5 & 6 & 12 & 14 \\
\hline Weighted Mean & 1.50 & 0.0 & 1.00 & 2 & 1.71 & 1.24 \\
\hline$\%$ to MPS & 50 & 0 & 33.33 & 66.66 & 57 & 41.40 \\
\hline $\begin{array}{l}\text { Product Mix of Competitive } \\
\text { Shops }\end{array}$ & 6 & 43 & 24 & 26 & 13 & 105 \\
\hline Weighted Mean & 1.20 & 1.67 & 1.41 & 1.37 & 1.30 & 1.39 \\
\hline$\%$ to MPS & 40 & 55.66 & 47 & 45.66 & 43.33 & 46.33 \\
\hline Image of Shop & 62 & 20 & 20 & 51 & 35 & 170 \\
\hline Weighted Mean & 2.48 & 1.64 & 2.05 & 1.76 & 1.84 & 1.95 \\
\hline$\%$ to MPS & 82.66 & 54.66 & 68.33 & 58.66 & 61.33 & 65.13 \\
\hline Other Factors & 0 & 1 & 0 & 0 & 3 & 4 \\
\hline Weighted Mean & 0.0 & 1.00 & 0.0 & 0.0 & 1.00 & 0.40 \\
\hline$\%$ to MPS & 0 & 33.33 & 0 & 0 & 33.33 & 13.33 \\
\hline
\end{tabular}

Source: Primary Data

Table 1 presents the data for the various influencing factors taken up by retailers for deciding their product mix, Following is the interpretation of the table:

Apparel: Under this retail business under study, the main influencing factor for deciding product mix is by keeping in line with the image of the shop at mean value of 2.48 with weighted score of 62 at $82.66 \%$ to MPS followed by the demand of customers with mean value of 2.00 at $66.66 \%$ to MPS. The third factor influencing the product mix is because of its financial strength at mean value of 1.88 at $62.66 \%$ to MPS. 


\section{DOI: 10.17148/IARJSET.2021.8863}

Household Appliances: Under this retail business, the main factor influencing the product mix is through the demand of customers with mean value of 2.59 at $83 \%$ to MPS with weighted score of 75 followed by profit margin with mean value of 1.92 at $64 \%$ to MPS. The third factor is the product mix of competing stores at mean value of 1.67 with weighted score of 43 at $55.66 \%$ to MPS.

Food and Grocery: Under this retail business, the main influencing factor of product mix is the profit margin with mean value of 2.50 at $83.33 \%$ to MPS followed by the demand of customers at mean value of 2.38 with weighted score of 50 at $79.33 \%$ to MPS. The third influencing factor is financial strength at mean value of 2.11 at $70.33 \%$ to MPS.

Mobile Phones: Under this retail business under study, the main factor of influence of product mix is the demand from customers at mean value of 2.85 with weighted score of 77 at $95 \%$ to MPS followed by image of the shop at $58.66 \%$ to MPS. The third influencing factor is the profit margin at mean value of 1.50 at $50 \%$ to MPS.

Cosmetics: Under this retail business, the main factor of deciding product mix is the profit margin at mean value of 2.50 at $83.33 \%$ to MPS with weighted score of 40 followed by demand from customers at mean value of 2.41 at $80.33 \%$ to MPS. The third main factor is the image of the shop at mean value of 1.83 with weighted score of 35 at $61.33 \%$ to MPS.

Table 2: Factors considered for Selection of New Products/Product Lines

(Score)

\begin{tabular}{|r|c|c|c|c|c|c|}
\hline Particulars & Apparel & $\begin{array}{c}\text { Household } \\
\text { Appliances }\end{array}$ & $\begin{array}{c}\text { Food \& } \\
\text { Grocery }\end{array}$ & $\begin{array}{l}\text { Mobile } \\
\text { Phones }\end{array}$ & Cosmetics & Total \\
\hline Availability of Funds & 12 & 11 & 27 & 40 & 25 & $\mathbf{1 0 5}$ \\
\hline Weighted Mean & $\mathbf{1 . 2}$ & $\mathbf{1 . 8 3}$ & $\mathbf{2 . 0 8}$ & $\mathbf{2}$ & $\mathbf{2 . 5 0}$ & $\mathbf{1 . 9 2}$ \\
\hline \% to MPS & 40 & 61 & 69.33 & 66.66 & 83.33 & $\mathbf{6 4 . 0 6}$ \\
\hline Profitability & 34 & 28 & 35 & 47 & 41 & $\mathbf{1 8 5}$ \\
\hline Weighted Mean & $\mathbf{1 . 7 9}$ & $\mathbf{1 . 1 2}$ & $\mathbf{1 . 7 5}$ & $\mathbf{2 . 2 4}$ & $\mathbf{2 . 0 5}$ & $\mathbf{1 . 7 9}$ \\
\hline \% to MPS & 59.66 & 37.33 & 58.33 & 74.66 & 68.33 & $\mathbf{5 9 . 6 6}$ \\
\hline Competition & 32 & 39 & 40 & 27 & 33 & $\mathbf{1 7 1}$ \\
\hline Weighted Mean & $\mathbf{1 . 8 8}$ & $\mathbf{2 . 1 7}$ & $\mathbf{1 . 9 0}$ & $\mathbf{1 . 6 9}$ & $\mathbf{1 . 6 5}$ & $\mathbf{1 . 8 6}$ \\
\hline \% to MPS & 62.66 & 72.33 & 63.33 & 56.33 & 55 & $\mathbf{6 1 . 9 3}$ \\
\hline Market Compatibility & 68 & 26 & 33 & 55 & 37 & $\mathbf{2 1 9}$ \\
\hline Weighted Mean & $\mathbf{2 . 3 4}$ & $\mathbf{2 . 0 0}$ & $\mathbf{1 . 9 4}$ & $\mathbf{2 . 2 0}$ & $\mathbf{2 . 1 8}$ & $\mathbf{2 . 1 3}$ \\
\hline \% to MPS & 78 & 66.66 & 64.66 & 73.33 & 72.66 & $\mathbf{7 1 . 0 6}$ \\
\hline Customer Demand & 10 & 76 & 45 & 46 & 41 & $\mathbf{2 1 8}$ \\
\hline Weighted Mean & $\mathbf{1 . 0 0}$ & $\mathbf{2 . 7 1}$ & $\mathbf{2 . 3 7}$ & $\mathbf{1 . 8 4}$ & $\mathbf{1 . 9 5}$ & $\mathbf{1 . 9 8}$ \\
\hline \% to MPS & 33.33 & 90.33 & 79 & 61.33 & 65 & $\mathbf{6 5 . 8 0}$ \\
\hline Weighted Mean & 0.00 & 0.00 & 0.00 & 2.00 & 2.00 & $\mathbf{0 . 8 0}$ \\
\hline \% to MPS & 0 & 0 & 0 & 66.66 & 66.66 & $\mathbf{2 6 . 6 6}$ \\
\hline
\end{tabular}

Source: Primary Data

Table 2 presents the factors considered by the retailers for the selection of new products or product lines. Following is the detailed interpretation of the table:

Apparel: Under this retail business, the main factor considered for selection of new products/ product line is market compatibility at mean value of 2.34 with weighted score of 68 at $78 \%$ to MPS followed by competition at mean value of 1.88 with weighted score of 32 at $62.66 \%$ to MPS. The third factor is profitability at mean value of 1.79 with weighted score of 34 at $59.66 \%$ to MPS.

Household Appliances: Under this retail business, the main factor considered for selection of new products/ product line is customer demand at mean value of 2.71 with weighted score of 76 at $90.33 \%$ to MPS followed by competition at mean value of 2.17 with weighted score of 39 . The third main factor considered for selection of new product/product line is market compatibility with mean value of 2,00 at $66.66 \%$ to MPS.

Food and Grocery: Under this retail business, the main factor considered for selection of new products/ product line is customer demand at mean value of 2.37 with weighted score of 45 at $79 \%$ to MPS followed by availability of funds at mean value of 2.08 at $69.33 \%$ to MPS. The third main factor is market compatibility with mean value of 1.94 at $64.66 \%$ to MPS with weighted score of 33 .

Mobile Phones: Under this retail business, the main factor considered for selection of new products/ product line is profitability at mean value of 2.24 at $74.66 \%$ to MPS with weighted score of 47 followed by market compatibility at 2.20 mean value with weighted score of 55 at $73.33 \%$ to MPS. The third main factor is availability of funds at mean value of 2 at $66.66 \%$ to MPS with weighted score of 40 .

Cosmetics: Under this retail business, the main factor considered for selection of new products/ product line is availability of funds at mean value of 2.50 at $83.33 \%$ to MPS followed by market compatibility at mean value of 2.18 with weighted 


\section{DOI: $10.17148 /$ IARJSET.2021.8863}

score of 37 at $72.66 \%$ to MPS. The third main factor is profitability with mean value of 2.05 at $68.33 \%$ to MPS with weighted score of 41 .

Table 3: Measures for ensuring Consistency in Product Mix (Score)

\begin{tabular}{|c|c|c|c|c|c|c|}
\hline Particulars & Apparel & $\begin{array}{l}\text { Household } \\
\text { Appliances }\end{array}$ & $\begin{array}{l}\text { Food \& } \\
\text { Grocery }\end{array}$ & $\begin{array}{l}\text { Mobile } \\
\text { Phones }\end{array}$ & Cosmetics & Total \\
\hline $\begin{array}{l}\text { Good Relationship with } \\
\text { Suppliers }\end{array}$ & 29 & 31 & 40 & 23 & 21 & 144 \\
\hline Weighted Mean & 1.93 & 1.94 & 2.22 & 1.92 & 1.62 & 1.92 \\
\hline$\%$ to MPS & 64.33 & 64.66 & 74 & 64 & 54 & 64.20 \\
\hline $\begin{array}{l}\text { Careful Selection of } \\
\text { Suppliers }\end{array}$ & 49 & 29 & 31 & 46 & 40 & 195 \\
\hline Weighted Mean & 2.33 & 1.71 & 2.07 & 1.92 & 2.22 & 2.05 \\
\hline$\%$ to MPS & 77.66 & 57 & 69 & 64 & 74 & 68.33 \\
\hline $\begin{array}{l}\text { Testing Samples before } \\
\text { Placing Orders }\end{array}$ & 43 & 43 & 30 & 85 & 57 & 258 \\
\hline Weighted Mean & 1.95 & 1.79 & 2.14 & 2.60 & 2.59 & 2.21 \\
\hline$\%$ to MPS & 65 & 59.66 & 71.33 & 86.66 & 86.33 & 73.80 \\
\hline $\begin{array}{l}\text { Offering Customer Preferred } \\
\text { Brands }\end{array}$ & 50 & 50 & 37 & 19 & 26 & 145 \\
\hline Weighted Mean & 2.45 & 2.17 & 1.95 & 1.27 & 1.53 & 1.87 \\
\hline$\%$ to MPS & 81.66 & 72.33 & 65 & 42.33 & 51 & 62.47 \\
\hline Updating Product Knowledge & 19 & 57 & 42 & 27 & 28 & 173 \\
\hline Weighted Mean & 1.36 & 2.38 & 1.75 & 1.93 & 1.75 & 1.83 \\
\hline$\%$ to MPS & 45.33 & 79.33 & 58.33 & 64.33 & 58.33 & 61.13 \\
\hline Other Factors & 6 & 1 & 0 & 0 & 3 & 10 \\
\hline Weighted Mean & 1.20 & 1.00 & 0.0 & 0.0 & 1.50 & 0.54 \\
\hline$\%$ to MPS & 40 & 33.33 & 0 & 0 & 50 & 24.66 \\
\hline
\end{tabular}

Source: Primary Data

Table 3 provides the data for the various means of ensuring consistency of product mix. Following is the detailed analysis of the table:

Apparel: Under this retail business under study the main measure of ensuring consistency in product mix is by offering customer preferred brands at mean value of 2.45 at $81.66 \%$ to MPS with weighted score of 50 followed by careful selection of suppliers at mean value of 2.33 at $77.66 \%$ to MPS. The third main measure of ensuring consistency is by testing samples before placing orders at mean value of 1.95 at $65 \%$ to MPS.

Household Appliances: Under this retail business under study the main measure of ensuring consistency in product mix is by updating the product knowledge at mean value of 2.38 at $79.33 \%$ to MPS with weighted score of 57 followed by offering customer preferred brands at mean value of 2.17 with weighted score of 50 at $72.33 \%$ to MPS. The third main measure of offering consistency is by maintaining good relationship with suppliers at mean value of 1.94 at $64.66 \%$ to MPS.

Food and Grocery: Under this retail business under study the main measure of ensuring consistency in product mix is by maintaining good relationship with wholesalers at mean value of 2.22 at $74 \%$ to MPS with weighted score of 40 followed by the testing of samples at mean value of 2.14 at $71.33 \%$ to MPS. The third main measure of ensuring consistency is by careful selection of suppliers at mean value of 2.07 with weighted score of 31 at $69 \%$ to MPS.

Mobile Phones: Under this retail business under study the main measure of ensuring consistency in product mix is by testing samples before placing orders at mean value of 2.60 with weighted score of 85 at $86.66 \%$ to MPS followed by keeping an update on product knowledge at mean value of 1.93 at $64.33 \%$ to MPS. The third main measure of ensuring consistency is by maintaining good relationship with suppliers and careful selection of suppliers at mean value of 1.92 at $64 \%$ to MPS.

Cosmetics: Under this retail business under study the main measure of ensuring consistency in product mix is by testing samples at mean value of 2.59 at $86.33 \%$ to MPS followed by the careful selection of suppliers at mean value of 2.22 with weighted score of 40 at $70 \%$ to MPS. The third main measure of ensuring consistency is by updating product knowledge at mean value of 1.75 at $58.33 \%$ to MPS.

Analysis of Pricing Mix of Retailers

Table 4: Objectives of Pricing of Products 
DOI: $10.17148 /$ IARJSET.2021.8863

(Score)

\begin{tabular}{|c|c|c|c|c|c|c|}
\hline Particulars & Apparel & $\begin{array}{l}\text { Household } \\
\text { Appliances }\end{array}$ & $\begin{array}{l}\text { Food \& } \\
\text { Grocery }\end{array}$ & $\begin{array}{l}\text { Mobile } \\
\text { Phones }\end{array}$ & Cosmetics & Total \\
\hline Earn Normal Profit & 7 & 60 & 27 & 0 & 46 & 119 \\
\hline Weighted Mean & 1.75 & 2.00 & 1.69 & 0.0 & 2.27 & 1.99 \\
\hline$\%$ to MPS & 58.33 & 66.66 & 56.33 & 0 & 75.66 & 60 \\
\hline Earn High Profit & 21 & 10 & 16 & 22 & 19 & 88 \\
\hline Weighted Mean & 1.62 & 1.67 & 1.45 & 2.20 & 1.58 & 1.74 \\
\hline$\%$ to MPS & 54 & 55.66 & 48.33 & 73.33 & 52.66 & 56.80 \\
\hline High Market Share & 18 & 4 & 0 & 9 & 22 & 53 \\
\hline Weighted Mean & 2.25 & 1.23 & $\mathbf{0 . 0}$ & 1.29 & 1.83 & 1.32 \\
\hline$\%$ to MPS & 75 & 41 & 0 & 43 & 61 & 44.00 \\
\hline Stabilize Prices & 49 & 39 & 36 & 48 & 41 & 213 \\
\hline Weighted Mean & 2.33 & 1.56 & 2.25 & 2.09 & 2.16 & 2.08 \\
\hline$\%$ to MPS & 77.66 & 52 & 75 & 69.66 & 72 & 69.26 \\
\hline Build Customer Relations & 62 & 69 & 67 & 62 & 44 & 304 \\
\hline Weighted Mean & 2.38 & 2.65 & 2.58 & 2.38 & 2.20 & 2.44 \\
\hline$\%$ to MPS & 79.33 & 88.33 & 86 & 79.33 & 73.33 & 81.26 \\
\hline Build Store Image & 23 & 48 & 23 & 27 & 23 & 144 \\
\hline Weighted Mean & 1.53 & 1.85 & 1.44 & 1.35 & 1.64 & 1.56 \\
\hline$\%$ to MPS & 51 & 61.66 & 48 & 45 & 54.66 & 52.06 \\
\hline $\begin{array}{l}\text { Set by Manufacturers/ } \\
\text { Wholesalers }\end{array}$ & 4 & 4 & 6 & 12 & 6 & 32 \\
\hline Weighted Mean & 1.33 & 2 & 2 & 2 & 2 & 1.87 \\
\hline$\%$ to MPS & 44.33 & 66.66 & 66.66 & 66.66 & 66.66 & 62.19 \\
\hline
\end{tabular}

Source: Primary Data

Table 4 presents the objectives of pricing by the retailers under study. Following provided the analysis of the data so collected:

Apparel: Under this retail business under study, the main objective of pricing of products is by building customer relations at mean value of 2.38 at $79.33 \%$ to MPS with weighted score of 62 followed by stabilization of prices at mean value of 2.33 with weighted score of 49 at $77.66 \%$ to MPS. The third main objective of pricing is because of high market share at mean value of 2.25 at $75 \%$ to MPS. Household Appliances: Under this retail business under study, the main objective of pricing of products is by building customer relations at mean value of 2.65 with weighted score of 69 at $88.33 \%$ to MPS followed by the objective to earn normal profits at mean value of 2.00 with weighted score of 60 at $66.66 \%$ to MPS. The third main objective is by building the store image at mean value of 1.85 with weighted score of 45 at $61.66 \%$ to MPS.

Food and Grocery: Under this retail business under study, the main objective of pricing of products is by building customer relations at mean value of 2.58 with weighted score of 67 at $86 \%$ to MPS followed by the objective to stabilize prices at mean value of 2.25 at $75 \%$ to MPS with weighted score of 36 . The third main objective is to earn normal profit at mean value of 1.69 with weighted score of 27 at 56.33\% to MPS. Mobile Phones: Under this retail business under study, the main objective of pricing of products is by building good customer relations at mean value of 2.38 with weighted score of 62 at $79.33 \%$ to MPS followed by the objective to earn high profit at mean value of 2.20 at $73.33 \%$ to MPS. The third main objective is to stabilize the prices at mean value of 2.09 with weighted score of 48 at $69.66 \%$ to MPS. Cosmetics: Under this retail business under study, the main objective of pricing of products is to earn normal profit at mean value of 2.27 with weighted score of 46 at $75.66 \%$ to MPS followed by building customer relationships at mean value of 2.20 with weighted score of 44 at $73.33 \%$ to MPS. The third main motive of pricing products is to stabilize the prices at mean value of 2.16 with weighted score of 41 at $73 \%$ to MPS.

Table 5: Pricing Strategies of Products

(Score)

\begin{tabular}{|r|c|c|c|c|c|c|}
\hline Particulars & Apparel & $\begin{array}{l}\text { Household } \\
\text { Appliances }\end{array}$ & $\begin{array}{l}\text { Food \& } \\
\text { Grocer } \\
\text { y }\end{array}$ & $\begin{array}{l}\text { Mobile } \\
\text { Phones }\end{array}$ & $\begin{array}{l}\text { Cosmetic } \\
\text { S }\end{array}$ & Total \\
\hline Psychological Pricing & 41 & 22 & 56 & 26 & 38 & $\mathbf{1 8 3}$ \\
\hline Weighted Mean & $\mathbf{1 . 9 5}$ & $\mathbf{2 . 0 0}$ & $\mathbf{2 . 1 5}$ & $\mathbf{1 . 6 3}$ & $\mathbf{1 . 9 0}$ & $\mathbf{1 . 9 2}$ \\
\hline \% to MPS & 65 & 66.66 & 71.66 & 54.33 & 63.33 & $\mathbf{6 4 . 1 9}$ \\
\hline Discounts & 51 & 59 & 47 & 34 & 39 & $\mathbf{1 9 7}$ \\
\hline Weighted Mean & $\mathbf{2 . 2 2}$ & $\mathbf{2 . 1 9}$ & $\mathbf{1 . 9 6}$ & $\mathbf{1 . 6 2}$ & $\mathbf{1 . 8 6}$ & $\mathbf{1 . 9 7}$ \\
\hline
\end{tabular}


Vol. 8, Issue 8, August 2021

DOI: $10.17148 /$ IARJSET.2021.8863

\begin{tabular}{|r|c|c|c|c|c|c|}
\hline \% to MPS & 74 & 73 & 65.33 & 54 & 62 & $\mathbf{6 5 . 6 6}$ \\
\hline Fixed Pricing & 44 & 37 & 50 & 39 & 56 & $\mathbf{1 9 9}$ \\
\hline Weighted Mean & $\mathbf{2 . 0 0}$ & $\mathbf{1 . 7 6}$ & $\mathbf{2 . 5 3}$ & $\mathbf{2 . 2 9}$ & $\mathbf{2 . 4 3}$ & $\mathbf{2 . 2 0}$ \\
\hline \% to MPS & 66.66 & 58.66 & 84.33 & 76.33 & 81 & $\mathbf{7 1 . 4 9}$ \\
\hline Special Event Pricing & 37 & 14 & 24 & 28 & 19 & $\mathbf{1 2 2}$ \\
\hline Weighted Mean & $\mathbf{1 . 9 5}$ & $\mathbf{1 . 2 7}$ & $\mathbf{1 . 5 0}$ & $\mathbf{1 . 6 5}$ & $\mathbf{1 . 3 6}$ & $\mathbf{1 . 5 4}$ \\
\hline \% to MPS & 65 & 42.33 & 50 & 55 & 45.33 & $\mathbf{5 1 . 5 3}$ \\
\hline Warranties/ Servicing & 3 & 45 & 4 & 53 & 27 & $\mathbf{1 2 2}$ \\
\hline Weighted Mean & $\mathbf{1}$ & $\mathbf{2 . 3 7}$ & $\mathbf{1 . 0 0}$ & $\mathbf{2 . 7 9}$ & $\mathbf{2 . 4 5}$ & $\mathbf{1 . 0 9}$ \\
\hline \% to MPS & 33.33 & 79 & 33.33 & 93 & 81.66 & $\mathbf{4 4 . 0 6}$ \\
\hline Other Strategies & 4 & 1 & 0 & 0 & 1 & $\mathbf{6}$ \\
\hline Weighted Mean & $\mathbf{2 . 0 0}$ & $\mathbf{1 . 0 0}$ & $\mathbf{0 . 0}$ & $\mathbf{0 . 0 0}$ & $\mathbf{1 . 0 0}$ & $\mathbf{0 . 8}$ \\
\hline \% to MPS & 66.66 & 33.33 & 0 & 0 & 33.33 & $\mathbf{2 6 . 6 6}$ \\
\hline
\end{tabular}

Source: Primary Data

Table 5 provides the various strategies adopted by the retailers in pricing of their products. Following provides the analysis of the table:

Apparel: Under this retail business under study, the main pricing strategy of products by the retailer is by giving discounts at mean value of 2.22 with weighted score of 51 at $74 \%$ to MPS followed by fixed pricing at mean value of 2.00 with weighted score of 44 at $66.66 \%$ to MPS. The third strategy is through psychological pricing at mean value of 1.95 with weighted score of 41 at $65 \%$ to MPS.

Household Appliances: Under this retail business under study, the main pricing strategy of products by the retailer is by providing warranties and services at mean value of 2.37 with weighted score of 45 at $79 \%$ to MPS followed by provision of discounts at mean value of 2,19 at $73 \%$ to MPS. The third strategy of pricing is the adoption of psychological pricing at mean value of 2.00 at $66.66 \%$ to MPS.

Food and Grocery: Under this retail business under study, the main pricing strategy of products by the retailer is through fixed pricing at mean value of 2.53 at $84.33 \%$ to MPS with weighted score of 50 followed by the adoption of psychological pricing at mean value of 2.15 with weighted score of 56 at $71.66 \%$ to MPS. The third main strategy is by provision of discounts at mean value of 1.96 with weighted score of 47 at $65.33 \%$ to MPS.

Mobile Phones: Under this retail business under study, the main pricing strategy of products by the retailer is by providing aftersales services and warranties at mean value of 2.79 with weighted score of 53 at $93 \%$ to MPS followed by fixed pricing at mean value of 2.29 at $76.33 \%$ to MPS. The third main strategy of pricing is special event pricing at mean value of 1.65 at $55 \%$ to MPS.

Cosmetics: Under this retail business under study, the main pricing strategy of products by the retailer is through fixed pricing at mean value of 2.43 with weighted score of 56 at $81 \%$ to MPS followed by psychological pricing at mean value of 1.90 at $63.33 \%$ to MPS. The third main strategy is by providing discounts at mean value of 1.87 at $62 \%$ to MPS.

Table 6: Pricing Methods for determining Selling Price

\begin{tabular}{|c|c|c|c|c|c|c|}
\hline Criteria & Apparel & $\begin{array}{l}\text { Househol } \\
\text { d } \\
\text { Applianc } \\
\text { es }\end{array}$ & $\begin{array}{l}\text { Food \& } \\
\text { Grocery }\end{array}$ & $\begin{array}{l}\text { Mobile } \\
\text { Phones }\end{array}$ & $\begin{array}{l}\text { Cosmetic } \\
\text { s }\end{array}$ & Total \\
\hline Cost-Plus & $\begin{array}{c}25 \\
(83.3)\end{array}$ & $\begin{array}{c}9 \\
(30.0)\end{array}$ & $\begin{array}{c}8 \\
(26.7)\end{array}$ & $\begin{array}{c}8 \\
(26.7)\end{array}$ & $\begin{array}{c}8 \\
(26.7)\end{array}$ & $\begin{array}{c}58 \\
(38.68)\end{array}$ \\
\hline $\begin{array}{l}\text { Suggested Price by } \\
\text { Suppliers }\end{array}$ & $\begin{array}{c}9 \\
(30.0)\end{array}$ & $\begin{array}{c}7 \\
(23.3)\end{array}$ & $\begin{array}{c}8 \\
(26.7)\end{array}$ & $\begin{array}{c}7 \\
(23.3)\end{array}$ & $\begin{array}{c}10 \\
(33.3)\end{array}$ & $\begin{array}{c}41 \\
(27.32)\end{array}$ \\
\hline Market Price & $\begin{array}{c}7 \\
(23.3)\end{array}$ & $\begin{array}{c}3 \\
(10.0)\end{array}$ & $\begin{array}{c}3 \\
(10.0)\end{array}$ & $\begin{array}{c}13 \\
(43.3)\end{array}$ & $\begin{array}{c}11 \\
(36.7)\end{array}$ & $\begin{array}{c}37 \\
(24.66)\end{array}$ \\
\hline MRP & $\begin{array}{c}6 \\
(20.0)\end{array}$ & $\begin{array}{c}28 \\
(93.3)\end{array}$ & $\begin{array}{c}29 \\
(96.7)\end{array}$ & $\begin{array}{c}11 \\
(36.7)\end{array}$ & $\begin{array}{c}5 \\
(16.7)\end{array}$ & $\begin{array}{c}79 \\
(52.68)\end{array}$ \\
\hline Bargains & $\begin{array}{c}9 \\
(30.0)\end{array}$ & $\begin{array}{c}2 \\
(6.7)\end{array}$ & $\begin{array}{c}2 \\
(6.7)\end{array}$ & $\begin{array}{c}7 \\
(23.3)\end{array}$ & $\begin{array}{c}1 \\
(3.3)\end{array}$ & $\begin{array}{c}21 \\
(14.00)\end{array}$ \\
\hline Other Methods & $\begin{array}{c}5 \\
(16.7)\end{array}$ & $\begin{array}{c}5 \\
(16.7)\end{array}$ & $\begin{array}{c}1 \\
\text { (3.hods } \\
\text { ado3) }\end{array}$ & $\begin{array}{c}0 \\
(0.0)\end{array}$ & $\begin{array}{c}0 \\
(0.0)\end{array}$ & $\begin{array}{c}11 \\
(7.34)\end{array}$ \\
\hline
\end{tabular}

Source: Primary Data

Table 7 provides the data on the methods adopted for determining prices of products by the retailers' understudy. Following provides an analysis of the table given: 


\title{
International Advanced Research Journal in Science, Engineering and Technology
}

\author{
Vol. 8, Issue 8, August 2021
}

\section{DOI: 10.17148/IARJSET.2021.8863}

Apparel: Under this retail business under study the main method of determining price of products is through cost-plus at $83.3 \%$ followed by suggested price by wholesalers and through bargains at $30 \%$ respectively. Household Appliances: Under this retail business under study the main method of determining price of products is at MRP at $93.3 \%$ followed by cost-plus pricing at $30 \%$. Food and Grocery: Under this retail business under study the main method of determining price of products is at the MRP at $96.7 \%$ followed by cost-plus pricing and suggested price by suppliers at $26.7 \%$ respectively. Mobile Phones: Under this retail business under study the main method of determining price of products is by following the market price at $43.3 \%$ followed by MRP at 36.7\%. Cosmetics: Under this retail business under study the main method of determining price of products is by suggested prices of retailers at $33.3 \%$ followed by market price and cost-plus pricing at $36.7 \%$ and $26.7 \%$ respectively.

\section{FINDINGS}

- The overall analysis on the influencing factors of deciding product mix are as follows:

Main influencing factor of deciding product mix: Demand from customers (Weighted Score 325, Avg. Mean Value= 2.45 with $80.86 \%$ to MPS)

Second influencing factor of deciding product mix: Profit Margin (Weighted Score 181, Avg. Mean Value= 2.03 with $67.66 \%$ to MPS)

Third influencing factor of deciding product mix: Image of Shop (Weighted Score= 170, Avg. Mean Value=1.96 at $65.12 \%$ to MPS)

The above analysis can infer that most retailers' main priority is the customers which is a very positive finding of the research.

- The overall analysis on the factors considered for selection of new product/product lines are as follows:

Main factor considered for selection of new product/product lines: Market Compatibility (Weighted Score 219, Avg. Mean Value $=2.13$ with $71.06 \%$ to MPS)

Second factor considered for selection of new product/product lines: Customer Demand (Weighted Score 218, Avg. Mean Value $=1.98$ with $65.80 \%$ to MPS)

Third factor considered for selection of new product/product lines: Competition (Weighted Score= 171, Avg. Mean Value $=1.86$ at $61.93 \%$ to MPS)

From the study of factors for selection of product lines, it can be inferred that the market plays an important role along with customers again which is a very positive finding especially from a customers' point of view.

- $\quad$ The overall analysis of the measures of ensuring consistency in product mix by the retailers is as follows:

Main measure of ensuring consistency in product mix: Testing samples before placing orders (Weighted Score 258, Avg. Mean Value $=2.21$ with $73.80 \%$ to MPS)

Second measure of ensuring consistency in product mix: Careful selection of suppliers (Weighted Score 195, Avg. Mean Value $=2.05$ with $68.33 \%$ to MPS)

Third measure of ensuring consistency in product mix: Good relationship with suppliers (Weighted Score $=144$, Avg. Mean Value $=1.92$ at $64.20 \%$ to MPS)

The above findings imply that sample testing is done by majority of the retailers implying that they base their quality on their own findings which proves to be a very important step towards customer retention and for finding new and potential customers. Another important finding is the scrutinization of suppliers for quality products implying that the retailers maintain a good supply chain.

- The overall analysis of the objectives of pricing of products by the retailers under study are as follows:

Main objective of pricing of products: Build customer relations (Weighted Score 304, Avg. Mean Value= 2.44 with $81.26 \%$ to MPS). Second objective of pricing of products: Stabilize prices (Weighted Score 213, Avg. Mean Value= 2.08 with $69.26 \%$ to MPS). Third objective of pricing of products: Earn normal profit (Weighted Score= 199, Avg. Mean Value $=1.99$ at $60 \%$ to MPS)

The above analysis infers that most of the retailers price their products to build customer relations which again shows that the retailers of Aizawl city focus on the 'Customer is King' concept. The study also reveals that stabilization of prices is also utmost important especially due to the fact that organized retailing is not much present in Aizawl city.

- $\quad$ The overall analysis of the pricing strategies of products by the retailers under study are as follows:

Main pricing strategy of products: Fixed Pricing (Weighted Score 199, Avg. Mean Value $=2.20$ with 71.49\% to MPS)

Second pricing strategy of products: Discounts (Weighted Score 197, Avg. Mean Value= 1.97 with 65.66\% to MPS)

Third pricing strategy of products: Psychological Pricing (Weighted Score $=183$, Avg. Mean Value $=1.92$ at $64.19 \%$ to

MPS). The above finding reveals that fixed pricing is mainly used as a strategy for pricing of products which infers and 


\title{
International Advanced Research Journal in Science, Engineering and Technology
}

\author{
Vol. 8, Issue 8, August 2021
}

\section{DOI: 10.17148/IARJSET.2021.8863}

goes in-line with the other findings i.e to stabilize the market prices so as to avoid over pricing and earn above normal profits. The study also reveals that discounts prove to be one of the main strategies which again is a very good way of retaining existing customers.

- Taking into account, all the retailers' majority of them uses the MRP for pricing of products at $52.58 \%$ followed by the method of cost plus at $38.68 \%$. The third main method of determining selling price among the retailers is through suggested pricing from the suppliers at $27.32 \%$. The findings again go in-line with the previous findings which is the stabilization of prices by using the MRP to sell the products along with maintenance of good supply chain by taking into account the opinion of the suppliers in pricing.

\section{SUGGESTIONS}

From the findings and observation of the study, the following are put forward to the retailers of the select categories with special focus to Aizawl city.

1. Retailers should incorporate the product mix of competitive shops rather than focusing more on the image of the shop since at the end of the day, the success of a business lies in standing out among its competition.

2. In order for the retailers to retain their name in the business sector, more focus should by pulled towards updating their product knowledge which would enhance consistency of product mix.

3. Special Event pricing strategy should be adopted especially during Christmas time where the Mizo's always go all out during the winter time in preparation for Christmas Day celebrations.

\section{CONCLUSION}

Marketing is universal, formally and informally, people and organizations are engaged in an infinite number of activities that can be clubbed in to marketing. Good and efficient marketing has become an increasing vital ingredient for the success of every business, big or small and has profoundly affected the day to day lived and is continually embedded in our every action-from the attire we wear to the appliances we use, technological gadgets to the food that we consume daily and to the ever-increasing utilization of superficial products to enhance the physical well-being.

Retail is a very significant sector in Mizoram wherein most goods and services are taken from elsewhere due to the lack of production industries within the state. From the study, it can be seen that the retailers are doing a great job focusing on customers needs, wants and desires along with the maintenance of a good supply chain management. The retails under study can in fact be said that they have achieved their aim of 'Customer is King' which is a key aspect in marketing as a whole.

\section{REFERENCES}

1. Adewalem G \& Oyewale, A (2013), 'Impact of Markeitng Strategy on Business Performance of Retail SME's: A Study of Select SME's on Oluyole Local Government, Nigeria', IOSR Journal of Business and Management, Vol 11, Issue 4, pp 59-66

2. Bijmolt et al. (2019), 'Challenges at the Marketing-Operations Interface in Omni-Channel Retail Environments', Journal of Business Research, Vol 4 (6), pp 1-10

3. Boyd, H and Levy, S (2001), 'New Dimensions in Marketing Analysis', Harvard Business Review, Sept- Oct 2001, pp 322-326

4. Bronnenberg, B \& Albuquerque, P (2002), ' Geography and Marketing Strategy in Consumer Packaged Goods', Advances in Strategic Management, Vol 5 Issue 2, pp 23-34

5. Cant, et al (2015), 'Product Strategy in Retailing: A Study on the Influence of Product Strategy', The Journal of Applies Business Research, Vol 31, No 2, pp 621-628

6. Egan, J (2000), 'Drivers to Relational Strategies in Retailing', International Journal of Retail \& Distribution Management, Vo79-36 128 , No 8 , pp 79-86

7. Kamenetz, A (2006), 'The Network Unbound', Fast Company, June 2006, pp 69-74

8. Koshi, A and Keller K (2016), 'Marketing Management: A South Asian Perspective', Himalaya Publishing House, pp 308-319

9. Kotler, P et al (2009), 'Marketing Management', Pearsons Education, $13^{\text {th }}$ Edition

10. Nair, R (2018), 'Consumption Dynamics and Demographics Effect on Food and Grocery Shopping Behaviour', IIMS Journal of Management Science, Vol. 9, Issue 2, pp 137-154

11. Rao, M (2001), 'The Marketing Sector in Indian Economy', Pearson Education, 10 ${ }^{\text {th }}$ Edition, pp 213-220

12. Rein, I and Haider, H (2008), 'Marketing Places across the World', Mc Graw Hill, New York

13. Shankalia, M et al (2018), 'A Study on Retailing Marketing Strategy on Apple Products', International Journey of Pure and Applied Management, Vol 119, No 17, pp 5510-339

14. Roberts, J et al (2009), 'Building Retail Tenant Trust: Neighbourhood versus Regional Shopping Centers', International Journal of Retail \& Distribution Management, Vol 38, No 8, pp 98-104

15. Shapiro, C (2008), 'Versioning: The Smart Way to Sell Information', Harvard Business Review , Nov-Dec 2008, pp 108-121

16. Sriram, VP et at (2017), 'Changing Retail Trends: Emerging Opportunities and Challenges of Indian Retail Industry', International Journal of Business and Management Invention, Vol 7, Issue 1, pp 25-29

17. Vasu, B (2019), 'A Study on the Satisfaction Level of Customers from Online and Retail Marketing with special reference to Kottayam District', International Journal of Research in Humanities, Arts and Literature, Vol 7, Issue 3, pp 515-520

18. Vijayan, P (2020), 'Effectiveness of Retail Marketing with Special Reference to Chavakkas Taluk, Thrissur District', Emperor International Journal of Finance and Management Research, Vol VI, pp 12-39 